Article

\title{
Urban Commons and Collective Action to Address Climate Change
}

\author{
Johan Colding ${ }^{1,2 *}$, Stephan Barthel ${ }^{1,3}$, Robert Ljung ${ }^{1,4}$, Felix Eriksson ${ }^{1}$, and Stefan Sjöberg ${ }^{5}$ \\ ${ }^{1}$ Department of Building Engineering, Energy Systems and Sustainability Science, University of Gävle, Sweden \\ 2 The Beijer Institute of Ecological Economics, Royal Swedish Academy of Sciences, Sweden \\ ${ }^{3}$ Stockholm Resilience Centre, Stockholm University, Sweden \\ ${ }^{4}$ Swedish Agency for Work Environment Expertise, Sweden \\ ${ }^{5}$ Department of Social Work and Criminology, University of Gävle, Sweden \\ * Corresponding author (johan.colding@hig.se)
}

Submitted: 2 September 2021 | Accepted: 20 October 2021 | Published: 22 February 2022

\begin{abstract}
Climate change and the coupled loss of ecosystem services pose major collective action problems in that all individuals would benefit from better cooperation to address these problems but conflicting interests and/or incomplete knowledge discourage joint action. Adopting an inductive and multi-layered approach, drawing upon the authors' previous research on urban commons, we here summarize key insights on environmentally oriented urban commons and elaborate on what role they have in instigating climate-proofing activities in urban areas. We deal with three types of urban commons, i.e., "urban green commons," "coworking spaces," and "community climate commons." We describe how allotment gardens, community gardens, and other types of urban green commons contribute to environmental learning that may boost understanding of environmental issues and which constitute important learning arenas for climate-change mitigation and adaptation. We also deal with the newly emerging phenomenon of coworking spaces that share many essential institutional attributes of urban commons and which can work for climate-change mitigation through the benefits provided by a sharing economy and through reduction of domestic transportation and commuting distance. Community climate commons represent commons where local communities can mobilize together to create shared low-carbon assets and which hold the potential to empower certain segments and civil society groups so that they can have greater influence and ownership of the transformation of reaching net-zero carbon goals. We conclude this article by identifying some critical determinants for the up-scaling of environmentally oriented urban commons.
\end{abstract}

\section{Keywords}

civic society; climate change; collective action; community climate commons; coworking spaces; mobilization; urban commons; urban green commons

\section{Issue}

This article is a part of the issue "The Politics and Aesthetics of the Urban Commons: Navigating the Gaze of the City, the State, the Market" edited by Peer Smets (Vrije Universiteit Amsterdam) and Louis Volont (Massachusetts Institute of Technology).

(C) 2022 by the author(s); licensee Cogitatio (Lisbon, Portugal). This article is licensed under a Creative Commons Attribution 4.0 International License (CC BY).

\section{Introduction}

Human-induced global warming through greenhouse gas emissions is unquestionably humanity's greatest challenge. The Sixth Assessment Report (IPCC, 2021) emphasizes that we will not be able to limit global warming to even $2^{\circ} \mathrm{C}$ without extensive reductions in greenhouse gas emissions. The impacts of global warming are largely unpredictable, with extreme weather events and more long-term effects of elevated sea levels, loss of biodiversity, and ultimately loss of resilience at planetary scales (Rockström et al., 2009).

Climate change and the coupled loss of ecosystem services pose major collective action problems. This is because humans as a group would benefit from taking action to deal with these problems, but few individuals 
have sufficient incentives to act alone (Nyborg et al., 2016). While much institutional inertia exists in effectively dealing with climate change (Colding et al., 2020), it is well worth asking what role collective-choice arenas could play for increased mobilization of civil society organizations to more effectively deal with the threats of climate change.

Horelli et al. (2015) show how self-organizing citizen initiatives, ranging from spontaneous events to longterm neighborhood developments aided by ICT, can have innovative impacts in urban life by activating new citizen groups. Devolution of property-right arrangements represents yet another means for initiating local climate action in society (Webb et al., 2021). Devolution entails that some or several of the bundles of rights and responsibilities associated with ownership are transferred to lower organizational levels (Ostrom \& Schlager, 1996).

Civil society organizations already play a significant role in the emergence of many self-organizing citizen initiatives and the emerging environmentally oriented urban commons in a wide range of urban settings (Colding et al., 2013). This is likely due to achieving a more holistic perspective on sustainability in recognition that social and natural systems are intimately linked and could best be described as social-ecological systems (Berkes \& Folke, 1998). The trend and ambition to establish "community centers" in marginalized neighborhoods or for certain marginalized groups is yet another example where urban commons can be designed and initiated. Community centers are public locations where members of a community gather for activities, social services, public information, education, and social mobilization. They can be open to the whole community or a specialized group within the greater community (Estes, 1997). Community work is closely related to the strategies and characteristics of the welfare state (Dominelli, 2020).

\subsection{Article Content, Outline, and Methodological Departure}

\subsubsection{Preconditions}

In this article we address what role urban commons could have in instigating collective action for climateproofing activities in urban areas. The concept "urban" herein includes settings ranging from rural towns to megacities. By "climate proofing" we mean the process of turning climate change into mitigation and/or adaptation strategies and programs (Kabat et al., 2005). Such strategies need to be broad and holistic and address both social and environmental issues. Raworth (2012) discusses how environmental and social factors are correlated, ranging from basic human material and social needs to planetary factors such as the atmosphere, climate, land use, flora, and fauna. Hence, Raworth provides a holistic perspective on sustainability. A similar perspective is proposed by Dominelli (2020), who highlights the need for creating a new paradigm-green social work-for promoting mobilization for environmental justice and care for the planet.

In line with these holistic propositions, we adopt a broad definition of urban commons while recognizing that definitions vary quite extensively (Colding et al., 2013). Here we describe urban commons as key institutions (including rules and norms) that regulate natural and societal resources in urban areas that are accessible to all members of a group that use, share, and/or manage resources together (Ostrom, 1990). Active common participation, social mobilization, and democratic influence are key features of urban commons (Stavrides, 2016). Urban commons are usually excludable for non-members, recognizing that it is only the local community or group of users that share, hold rights, and set the rules for how to manage their commons (Berkes, 1989; Ostrom, 2008). The exclusion of non-members can be important for sustaining the commons and avoiding the tragedy of the commons (Hardin, 1968).

The commons may be synonymous with the public, but the public becomes a commons only when the citizens have real influence over public resources. Central to the notion of the commons is the community itself, not whether it exists in a private or public context and ownership (Colding \& Barthel, 2013; Ostrom, 1990). Hess (2008) describes a whole range of "new commons" that recently have evolved or lately have been recognized as commons, ranging from cultural commons, knowledge commons, neighborhood commons to medical and health commons.

Previous research indicates that venues that support physical meetings among people are key for collective action. When participants share a common interest and interact with one another in groups, the probabilities of their developing social norms to govern repetitive relationships are much greater than in situations lacking such characteristics (Ostrom, 2005). That sharing an interest can be a sufficient condition for mobilization of collective action has been demonstrated in the urban policy and planning arena. Rydin and Pennington (2000), for example, argue that sharing certain traits and the enjoyment of collective effort, often is a sufficient incentive for greater participation in planning activities.

Research in environmental psychology also indicates that group-based learning is more effective for people to learn about climate change than individual learning (Holmgren et al., 2019; Xie et al., 2018). The work on common property systems by Elinor Ostrom supports this line of argument, emphasizing the critical role that collective choice arenas play in long-enduring resource management systems (Ostrom, 2005).

\subsubsection{Methodological Departure}

In writing this article, we have adopted the inductive approach used by Barthel et al. (2021), enabling multilayered and cross-disciplinary collaboration and analysis 
from a diverse set of scientific disciplines in the natural, social, and humanistic sciences in which the authors hold expert knowledge. The approach was originally developed by Conrad and Sinner (2015) as a way to encourage scholars to work together to create new possibilities and interactivity with other professionals and community groups to explore questions, generate knowledge, and express shared understandings of phenomena. The purpose here has been to present and elaborate on a set of environmentally oriented urban commons with the potential to instigate collective climate proofing in society. We here elaborate on three types of environmentally oriented urban commons that the authors hold expert knowledge of, including "urban green commons," "coworking spaces," and "community climate commons." In line with the classification made by Hess (2008), the latter two represent "new commons" that more recently have been classified as commons.

\section{Environmental Urban Commons}

\subsection{Urban Green Commons}

Colding and Barthel (2013, p. 159) have defined urban green commons as:

Physical green spaces in urban settings of diverse land ownership that depend on collective organization and management and to which individuals and interest groups participating in management hold a rich set of bundles of rights, including rights to craft their own institutions and to decide whom they want to include in such management schemes.

Urban green commons, as dealt with here, allow for a considerably larger set of the urban populace to actively manage land in cities. Few property rights regimes enable a larger set of urban residents to actively "manage" land in cities. As Table 1 shows, most natural and semi-natural land in cities only offers access rights to land but does not offer management rights to ordinary citizens.

Most urban green commons involve quite traditional landforms, such as "allotment areas" that are a customary feature in European urban landscapes and that historically have played a role by ensuring food security during crises (Barthel \& Isendahl, 2013). Allotment associations effectively deal with the problem of congestion resulting from open access through fixed sizes and numbers of individual plots, and by membership fees. Leaseholds between the allotment association and the landholder tend to be rather long, lasting up to 25 years in some cases.

Exclusion of outsiders to allotments is often physically embodied in that fences or hedges surround these areas. A more recent trend in the UK is to create community allotments that can be used by large groups of people such as schools (Speak et al., 2015). Allotments differ from private domestic gardens by being subject to prescriptive gardening association codes. These local and national codes determine how management is carried out (Cabral et al., 2017). Barthel et al. (2010) refer to allotment gardens as communities-of-practice (Wenger, 1998) that involve acquisition, transmission, and modification of ecological practices and local ecological knowledge.

"Community gardens" are another example of urban green commons, although they represent a considerably more unstable form of commons, having a tradition of being self-organized (Ruitenbeek \& Cartier, 2001), and often constituting an interim use for vacant land awaiting construction (Colding, 2011). They represent a very diffuse phenomenon with a long tradition and history both across the EU and in the rest of the world. Community gardens often involve small land plots used for food cultivation by urban dwellers with limited ability to own land. They represent bottom-up, community-based efforts to grow food (Okvat \& Zautra, 2011). Only a tiny proportion of the community gardens in the US are permanent and their fate is largely determined by the real estate market (Linn, 1999).

In comparison to allotments, community gardens are surrounded by less strict regulations (Cabral et al., 2017). Many community gardens afford a holistic framework for sustainability by integrating environmental restoration, community activism, social interaction, cultural expression, and food security (Krasny \& Tidball, 2009).

Even whole public parks, or portions of parks, are sometimes managed as urban green commons. The city

Table 1. Bundle of rights to nature from a citizen perspective in relation to different landforms.

\begin{tabular}{lllll}
\hline & Residential garden & Tree alleys & Parks & Urban green commons \\
\hline Access & $\mathrm{x}$ & $\mathrm{x}$ & $\mathrm{x}$ & $\mathrm{x}$ \\
Withdrawal & $\mathrm{x}$ & & $\mathrm{x}$ & $\mathrm{x}$ \\
Management & $\mathrm{x}$ & & & \\
Exclusion & $\mathrm{x}$ & & Commons \\
Alienation & $\mathrm{x}$ & Public & Public & \\
Property rights regime & Private & & & \\
\hline
\end{tabular}

Notes: In residential gardens, only the owner can conduct gardening. In street tree alleys and parks, people normally only have access rights; urban green commons increase the opportunity for urban residents to have management and access rights to urban ecosystems; $(\mathrm{x})$ = partial rights. Source: Modified and adapted from Colding et al. (2013). 
of Berlin, for example, holds a number of public parks that are managed (not owned) by collective user groups (Bendt et al., 2013). Membership to these areas is either formally defined or according to ex post criteria such as residency or acceptance by existing members in the group.

Urban "community forests" are yet another example of Urban green commons that are collectively managed by a diverse set of stakeholders. Community forests in the UK are often located in green belts and often cover several hundred hectares of land (Colding, 2011). "Sacred groves" are common in Asia and Africa (Colding $\&$ Folke, 2001). A sacred grove is usually a part of a forest set aside for spiritual or religious purposes and therefore considered sacred, and the removal of even dead wood is strictly taboo (Gadgil \& Vartak, 1974). Due to increasing urbanization pressures, many sacred groves are protected as cultural heritage sites. In some parts of the world they represent the only remaining virgin forests (Colding \& Folke, 2001).

\subsubsection{Environmental Learning as a Co-Benefit of Urban} Green Commons

Bendt et al. (2013) found that much holistic learning takes place in urban green commons, including learning about gardening and local ecological conditions, learning about self-organization and social integration, learning about the politics of urban space, and learning about social entrepreneurship. For example, respondents state that they learned about micro-ecological conditionse.g., soil quality, shade patterns, heat levels in different parts of the garden, and local wind patterns-and also became more aware of climate change and displayed an increased concern for environmental issues. Hence, urban gardening, which is an active way of learning by doing, instills participants with new, or reinforced, awareness of ecological issues and processes that are operating at greater scales than the gardens themselves. Barthel et al. (2010) provide ample examples of ecological learning among allotment holders-knowledge that may or may not be transmitted to others via mimicking or oral means.

Suffice to say, we view urban green commons as key institutional arrangements for civil society groups to become more deeply involved in the resilience building of cities and local communities through combining climate-change adaptation with climate-change mitigation measures. Urban planners and policymakers should nurture such property rights arrangements for harnessing the climate-change agency of different civil society groups (Colding et al., 2020). As elaborated upon here, urban green commons can grant urban residents the right to actively engage in the management of both public and private land and this, in turn, contributes to environmental learning. As shown in previous studies, local-level institutions can respond to environmental feedback and surprises much faster than formal insti- tutions used by centralized agencies (Folke et al., 2007). This is because informal institutions are locally crafted and socially enforced by the group of users themselves; hence, their flexible character renders them sensitive to environmental variability. Many of the practices that are carried out in urban green commons promote climate proofing. For example, urban gardening that may abate food shortage during periods of crisis (i.e., adaptation) could reduce unnecessary transports. Protecting community forests and green infrastructure for biodiversity reasons in community forests, allotments, and even in public parks (i.e., adaptation) also helps to sequester carbon from the atmosphere (i.e., mitigation). Protecting green structures and wetlands to adapt cities to the impacts of droughts and flooding is another adaptation strategy that enhances climate resilience while sequestering carbon and reducing carbon emissions generated by traffic, fossil fuel-based power plants, and other forms of combustion sources (Jansson \& Nohrstedt, 2001).

To create opportunities for civil society groups to act against climate crises, property rights regimes need to exist to promote such advancement. A strengthened socio-economic investment in urban green commons could help instigate climate-change adaption in the wider society and could, in the long run, be more effective for dealing with the climate crisis than solely focusing on achieving specific mitigation targets that often lack a socio-cultural context (Colding et al., 2020). As studies also indicate, socio-cultural factors often represent a strong motive for people to take up urban gardening (Oddsberg, 2011). Interest in partaking in urban green commons can, in a more theoretical sense, be interpreted as an expression of the antithesis of globalization and for proliferating cultural identities that increasingly have become diluted (Tomlinson, 2003). Identity in this sense denotes the rising power of local culture ("glocalization") that offers resistance to the market forces of globalization (Tomlinson, 2003). This line of argument is supported by Pearsall et al. (2017) and Saldivar-Tanaka and Krasny (2004) who found that the preservation of cultural identities was the strongest motive for respondents to take up urban gardening in several examined community gardens in the US.

\section{Coworking Spaces}

Coworking spaces share some essential institutional attributes of urban common property systems. First of all, they represent physical locations or meeting places in cities, suburbs, and even rural areas, bringing people together. Secondly, and similar to other forms of urban commons, they are not freely open to everyone, but to a subset of people that become active members through rental fees and/or admittance fees. Thirdly, sharing of certain resources is a distinct characteristic of coworking spaces. To what degree participants in coworking spaces hold collective-choice rights and may influence organizational decisions is, however, a question not looked into 
here due to lack of empirical findings. However, this characteristic should be explored in further studies.

Coworking has globally grown on a regular basis during the last two decades. The definition of coworking varies depending on the interpreter. An accepted description is that it stands for a fundamentally new way of working in that two or more people work in the same place but for different companies (DTZ, 2014). Coworking can be described as a mixture of working from home and public workspaces (Brown, 2017). It represents but one example of the ample emergence of autonomous ways of working and living, such as mobile work, flex office, platform-based entrepreneurship, virtual collaborations, DIY, the work-from-home phenomenon, digital nomads, and other emergent trends of organizing work practices (de Vaujany et al., 2021).

Freelance engineer Brad Neuberg is by many seen as the pioneer of the concept when starting the Spiral Muse in San Francisco in 2005. Neuberg launched the Spiral Muse for lack of like-minded people to boost exchange knowledge and experience through creative flows that arose through collaboration with other individuals (Waters-Lynch et al., 2016). Similar examples then spread to other cities around the US and eventually to Europe.

The sharing of office space among employees of different interests and occupations has rapidly spread in conjunction with the growth of digitalization (Luo \& Chan, 2020), especially in relation to the development of smart cities where coworking is seen as an important tool of a sharing economy that aims at reducing resource use by joint use of goods and services (Akande et al., 2020). Luo and Chan (2020) have estimated that about 1.7 million people worked in 19,000 coworking offices worldwide by the end of 2018, in contrast to the 160 coworking offices that existed in 2008. It is not only freelancers and self-employed people that take advantage of shared office landscapes, but also technology giants such as Microsoft and Google (Bouncken et al., 2020). Many companies have increasingly begun to develop their physical office landscapes during the past 20 years to improve the flow of communication, collaboration, and innovation among employees (Bouncken et al., 2020).

\subsection{Drivers Behind Coworking}

There is a multitude of reasons behind the rapid growth of coworking spaces, some of which converge and reinforce each other. One key determinant was the global economic recession of 2008. After the financial crisis, office rents in many cities rose dramatically (Yang et al., 2019). In many contemporary urban regions, office shortages are as common as housing shortages (Börjesson, 2018). This affects start-ups and independent entrepreneurs as rents, equipment, and resources are significant costs for young companies (Yang et al., 2019). Sharing office space and necessary equipment, there- fore, becomes a viable alternative for survival (Räisänen et al., 2020).

Coworking is directly linked to the "gig economy" that broke out during the financial crisis in 2008 when employment conditions became more unstable. Journalist Tina Brown suggested the term "gig economy" when she observed the shift between more traditional working hours to more and more people choosing their own working hours (Goswami, 2020). Gig economics is characterized by short-term employment with specific work assignments, hence the word "gig" alluding to the music scene (Schroeder et al., 2019).

One should not underestimate the great need that people have to meet physically, something that the Covid-19 pandemic reminds us of. For many companies, physical meetings are an important strategy for business development. Moriset (2013) describes how the term "creative city" (Scott, 2006) aims to maximize opportunities for face-to-face meetings that in turn nurture the exchange of "tacit knowledge" (Polanyi, 1966), a concept that has received much attention from economic geographers (Moriset, 2013). Many researchers regard tacit knowledge as "a key determinant of the geography of innovative activity" (Gertler, 2003, p. 79). While codified knowledge-like "raw information"-may be exchanged and traded at distance through digital platforms and technologies, the production and exchange of tacit knowledge involve social and cultural components and require some intimate trust between participants. Moriset (2013) argues that this level of trust is often achieved through close contact during in-person meetings, which occur in selected places.

In her studies of common-property systems, Elinor Ostrom stressed the key role of eye-to-eye contact for trust building in social settings where individuals cooperate to achieve desired ends (see, e.g., Ostrom, 1990). Climate change represents a major collective action problem that depends on trust building and cooperation among a greater set of people. Many of the dimensions that are deemed key by social scientists for achieving sustainability (e.g., social cohesion, social inclusion, human well-being, and quality of life) depend likewise on the physical meetings of community members.

\subsubsection{Environmental Co-Benefits of Coworking}

Domestic transport and travel account for a significant part of today's greenhouse gas emissions. In Sweden, for example, they accounted for about 17 million tons of carbon dioxide equivalents of greenhouse gas emissions in 2019. This corresponds to about a third of Sweden's total emissions within its borders.

While positive environmental outcomes have been reported for teleworking in general (Hook et al., 2020), empirical research has revealed an overestimation in reducing greenhouse gas emissions (Ohnmacht et al., 2020). Besides the reported potential reductions of workfrom-home, the travel time saved by shorter trips for 
work reasons may be reinvested in travel for other reasons, thus leading to rebound effects (Ohnmacht et al., 2020).

While there are few empirical studies so far on the environmental gains of coworking, the ones that do exist suggest that it can contribute to reduced transportation and that this part can be significant. For example, Kylili et al. (2020) showed that the environmental impact on Cyprus was reduced by $43 \%$ through coworking by reducing daily commuting. In a study by Eriksson (2021) in Sweden, a significant difference in kilometer distance was observed between people commuting to coworking spaces relative to their previous commuting behavior to regular offices. This difference was not trivial, as coworking reduced commuting by a significant distance per day.

Moreover, in a study of coworking in Switzerland, Ohnmacht et al. (2020) found that $\mathrm{CO}_{2}$ emissions from commuting for work were significantly lower for urban coworking spaces than for rural coworking spaces. They concluded that coworking spaces have the potential to reduce $\mathrm{CO}_{2}$ emissions from commuting by $10 \%$.

The notion of the sharing economy that coworking centers rest upon also plays an important role in achieving several Agenda 2030 goals (Akande et al., 2020). Sharing economy creates new jobs, new income forms, and business ventures. From a social perspective, it creates new social ties and helps build communities (Akande et al., 2020). Despite a lack of empirical evidence from sustainability assessments of sharing initiatives, sharing economy has been shown to contribute to increased resource efficiency and climate-change mitigation through the utilization of redundant assets (Harris et al., 2021). While tool sharing does not demonstrate a large potential for national reductions, office sharing has been found to have a significant potential to reduce greenhouse gas emissions (Harris et al., 2021).

Buildings use a lot of energy to heat, cool, and illuminate offices as well as to operate various types of office equipment. This energy use is not insignificant. Rivas et al. (2020) found that office buildings account for one-fifth of all commercial energy consumption. Estimates determined by the Swedish Environmental Research Institute (2019) show that shared office types have the potential to reduce energy use and greenhouse gas emissions by as much as 38-70\% depending on how the office spaces are used. These estimates do not include savings from work equipment and furniture.

\subsubsection{Public vs Social Spaces}

Coworking spaces are initiated by both top-down and bottom-up forces (Moriset, 2013). Due to the ongoing decline of the national welfare states, the private sector increasingly replaces funding of services that previously were provided by various governmental bodies. For example, hybrid forms of contractual relations between the public and private sectors are increasing all over the world (Vincent-Jones, 2000). Public-private partner- ships (PPPs) are often used to re-develop and manage public spaces, especially when capital investments are needed. Such a development may not always be socially sustainable. According to modern conceptions of property rights, ownership of public space also implies control over the range of permissible uses of a particular location (Kohn, 2004). While PPPs arrangements may not directly lead to the loss of public space, they can affect public space in more indirect ways, such as through increased crowd control and by creating more social spaces that fragmentize formerly public spaces. Kohn (2004) refers to such intrusion of private spaces into public spaces as "café creep," referring to the ongoing gradual privatization in many cities and which cuts residents off from places that previously were public. Unless revenues also are redistributed to the public sector from a profit-maximizing private sector, PPPs arrangements may not always be socially desirable from a democratic point of view. As an effect of the globalized market economy, there is an increasing dislodging of locally supplied resources and responsibilities that contributes negatively to public health, welfare, and people's living conditions, and is thus not socially sustainable.

On the other hand, coworking spaces could positively contribute to the loss of many "third places" as experienced in many cities due to lack of public funding (Moriset, 2013). Third places describe places that are separate from the two usual social environments of home ("first place") and workplace ("second place"); hence, these represent places where people convene and socialize in a free, informal manner and that are irreplaceable in the production of the urban social fabric (Oldenburg, 1989). This includes public libraries, bookstores, parks, and various community centers. The fact that many coworking spaces were founded based on self-organization in the beginning era of the coworking movement (2005-2010) is testimony to their role as serving as new forms of physical meeting places in the digital era.

\section{Community Climate Commons}

Given the gravity of the issue at stake, the scientific literature is surprisingly devoid of relevant examples of urban commons that are specifically targeted for climatechange abatement. Webb et al. (2021, p. 5) refer to such commons as "local climate commons," representing commons where local people are "coming together to create shared low carbon assets," including renewable energy, housing, woodland, and food cultivation. The purpose of this type of commons is to empower local communities so that they can have greater participation and ownership of the transition to net-zero emissions that are locally tailored and locally driven while also addressing inequality. To bring about such a shift, Webb et al. (2021) argue that three key conditions are required:

- Widespread devolution of power and resources; 
- Setting ambitions for climate action and the community;

- Policies to drive community climate action and build community-owned green assets.

We have previously addressed the first point regarding the devolution of powers down to local levels. Devolution of formal rules to informal institutions could nurture social norms that may have greater power to facilitate collective action. McGinnis and Ostrom (1992) argue that the most successful institutions to control environmental problems are those that are best matched to micro- or meso-level environments rather than institutions determined at a global level. The notion of "community" is central here and entails everything from a congregation of people living together, to civil society groups or organizations, and even whole urban neighborhoods (Webb et al., 2021). The community concept includes both a delimited geographical area and an interest-based social community of people (Popple, 2015). Within the community discourse, scholars stress that successful community mobilization presupposes a number of components (see, e.g., Fook, 2016; Popple, 2015; Pyles, 2020; Sjöberg et al., 2015):

- Creating interaction, dialogue, confidence, and collective identity within the community;

- Spreading knowledge and awareness of identified common problems;

- Promoting activation, participation, and democratic influence;

- Building networks, cooperation, and collective resources;

- Organizing common activities and collective empowerment to act for change and development.

Active common participation, democratic influence, and social mobilization are key features in the creation of urban commons where people meet and act together (Stavrides, 2016). Commons can also include the social practice of managing a resource by a community of users that self-governs through institutions that it has created. To create collective action for climate-proofing activities, it is important to have places to meet in the urban space. This means places where people and organizations can meet, exchange experiences, and arrange meetings for knowledge acquisition and awareness-raising. We then believe that community centers can have a key role in the social mobilization of community climate commons. Community centers are common locations where members of a community can gather for education, lectures, autonomous dialogue, activities, and social mobilization. Community centers can serve as a foundation for commons that can evolve both top-down (e.g., initiated by public actors) or bottom-up (driven by, e.g., civil society organizations and through different forms of hybrid governance). Besides being a multi-service location, it might work as a node of cooperation and community mobilizing agent for increased participatory democracy (Estes, 1997; Sjöberg \& Kings, 2021). Community centers have been of interest within social sciences ever since the settlement movement and the labor movement's establishment of such centers in the 19th century (Kohn, 2001; Yan, 2004). In Sweden so-called Folkets hus (literary meaning "the People's houses") were built by the labor movement around the country starting in 1932, and they still work as important community centers for education, debate, and social awareness (Kohn, 2001). Community commons have the potential to function as catalysts of mobilization for climate action, where venues in the built environment can serve as places for various community-based organizations and actors to start to mobilize for collective climate action in deliberative democratic processes (Dryzek \& Niemeyer, 2019).

There are many examples of how community centers have been important for the mobilization of civil society. A local example in Stockholm is the community center Folkets Husby in the marginalized suburb of Husby. The premises are owned by the municipal public housing company and the community center is self-governed by local voluntary associations. Folkets Husby has managed to generate a strong local mobilization, started a cooperation with the long-established nationwide organization Folkets Hus, and has run new premises in the neighborhood since 2016. Today, this community center is run by some 50 associations and many residents have become members involved in the center in different ways (Sjöberg \& Kings, 2021). The center is democratically governed by the members and primarily financed by state or municipal grants. Folkets Husby has served as a basis for getting people and organizations from various backgrounds together and has resulted in social mobilization for the socially sustainable development of segregated neighborhoods in Stockholm. Using the community center as a basis for their activities, the organized civil society actors have successfully mobilized to put issues such as social exclusion and segregation on the agenda, including meetings and discussions with, e.g., decision-making politicians. We consider that such community centers are important cornerstones and that they have the potential to serve as nodes and basis for mobilization for climate action and change, and the formation of community climate commons.

\subsection{Community Climate Commons in the Built Environment}

The built environment is of particular importance for instigating community climate commons since this is where the majority of people reside. By the built environment we mean the human-made space in which people live, work, and recreate on a day-to-day basis (Roof \& Oleru, 2008). Setting ambitions for the climate proofing of the built environment is also in the self-interest of most real estate companies, whether public, non-profit, or private profit-oriented real estate companies. Suffice 
to say, it is also in the interest of the tenants to have a stake in the climate proofing of their local outdoor environments, such as courtyard and backyard habitats and nearby green spaces. Community climate commons are also important to nurture to increase awareness and knowledge about climate change in wider society. Interestingly, research in environmental psychology suggests that group-based learning about climate change is more effective than individual learning (Holmgren et al., 2019; Xie et al., 2018).

It is first when physically built community centers function so that the people who are there are active participants who design and democratically decide which activities are to be carried out, that the community centers become urban commons. Community centers then have the potential to function as catalysts of mobilization for climate action, where venues in the built environment can serve as places for various community-based organizations and actors to start mobilizing for climateproofing action.

We suggest that local community centers and outdoor environments of different types are suitable locales around which to create climate commons. In many cases, present-day courtyards need to be retrofitted to better buffer against undesirable climate-change effects. Both technical and nature-based solutions could be harnessed to achieve climate adaptation, e.g., underground tanks to store rainwater, green roofs, the planting of species to support pollinators, creation of bioswales and wetlands, wind and solar power systems, etc. The use of augmented reality technology (https://bit.ly/33NCJsu) can be useful for designing community climate commons by visualizing different types of design solutions and can also provide information about ecosystem services, biodiversity, and linked social activities.

\section{Concluding Remarks}

Much "devolutionary inertia" acts as a real barrier for facilitating climate-proofing in present-day society. There probably are many reasons for this, such as a lack of trust in, and the unwillingness of, local governments to transfer power (read "property rights") to groups of non-authorial stakeholders. High transaction costs might be another reason as well as lack of financial means for local governments to handle devolution issues. We also believe that there is a lack of knowledge about the virtues of urban commons more generally in society. Hence, an article of this kind may shed new light on the environmental ramifications of urban commons and identify ways to make them even more relevant for climate proofing in the near future.

A number of critical questions still circumscribe an upscaling of urban commons in wider society. One refers to the question of private-public interests and cooperation. We see it as crucial that the public sector actively supports urban common projects. We are not sure however to what extent private interests could back up and assist the development of urban commons. And is it feasible or even desirable that governments, e.g., provide economic incentives (tax cuts, etc.) for private companies that invest in urban commons projects?

Another critical question is to determine to what degree participants in coworking spaces hold collectivechoice rights and may influence organizational decisions. In conjunction with this question, there likely is a continuum of different types of coworking spaces, from those being collectively run and managed to those being privately run and managed. This needs to be determined in future studies since this likely influences to what degree coworking spaces can instigate collective climate-change action more broadly in society.

Moreover, is there a critical size for urban commons for them to function well? Is this contingent on the number of people participating, or the size of an area managed as urban commons? Both of these questions are likely interdependent. As pointed out above, trust-building is an essential characteristic of well-functioning common property systems. As empirical research suggests (Feinberg et al., 2020; Rogge et al., 2018), smaller group sizes are more likely to sustain trust and social cohesion. This, perhaps, also indicates that the "community" to start with should not be too big and involve too many stakeholders, also taking into consideration Ostrom's critical design principle of having welldemarcated resource areas to be governed and/or managed. That might be an argument for instigating locally based community climate commons which could then serve as a basis for building strong networks for collective climate-proofing action.

\section{Acknowledgments}

This research has been supported through a grant facilitated by the Swedish Foundation for Strategic Environmental Research (Mistra) and FORMAS, within the research program Fair Transformation to a Fossil Free Future (FAIRTRANS), hosted by the Stockholm Resilience Centre, Stockholm University. The work is also supported through means within the research program Urban Commons at the University of Gävle.

\section{Conflict of Interests}

The authors declare no conflict of interests.

\section{References}

Akande, A., Cabral, P., \& Casteleyn, S. (2020). Understanding the sharing economy and its implication on sustainability in smart cities. Journal of Cleaner Production, 277. https://doi.org/10.1016/j.jclepro.2020. 124077

Barthel, S., Folke, C., \& Colding, J. (2010). Socialecological memory in gardening: Retaining the capacity for management of ecosystem services. Global 
Environmental Change, 20, 255-265.

Barthel, S., \& Isendahl, C. (2013). Urban gardens, agricultures and waters: Sources of resilience for longterm food security in cities. Ecological Economics, 86, 224-234.

Barthel, S., Colding, J., Hiswåls, A-S., Thalén, P., \& Turunen, P. (2021). Urban green commons for socially sustainable cities and communities. Nordic Social Work Research. https://doi.org/10.1080/ 2156857X.2021.1947876

Bendt, P., Barthel, S., \& Colding, J. (2013). Civic greening and environmental learning in public-access community gardens in Berlin. Landscape and Urban Planning, 109, 18-30. http://dx.doi.org/10.1016/ j.landurbplan.2012.10.003

Berkes, F. (1989). Common property resources. Ecology and community-based sustainable development. Belhaven.

Berkes, F., \& Folke, C. (1998). Linking social and ecological systems: Management practices and social mechanisms for building resilience. Cambridge University Press.

Börjesson, C. (2018). Coworking-kontor, en exponentiell trend-Fastighetsägarnas nya verklighet. [Coworking office, an exponential trend-The real-estate owners' new reality]. Fastighetsägarna. https://www. fastighetsagarna.se/globalassets/rapporter/ stockholms-rapporter/coworking--kontor-enexponentiell-trend.pdf?bustCache $=1638173728185$

Bouncken, R. B., Aslam, M. M., \& Qiu, Y. (2020). Coworking spaces: Understanding, using, and managing sociomateriality. Business Horizons, 64(1), 119-130. https://doi.org/10.1016/j.bushor.2020.09.010

Brown, J. (2017). Curating the "third place"? Coworking and the mediation of creativity. Geoforum, 82, 112-126. https://doi.org/10.1016/j.geoforum.2017. 04.006

Cabral, I., Keim, J., Engelmann, R., Kraemer, R., Siebert, J., \& Bonn, A. (2017). Ecosystem services of allotment and community gardens: A Leipzig, Germany case study. Urban Forestry and Urban Greening, 23, 44-53.

Colding, J. (2011). Creating incentives for increased public engagement in ecosystem management through urban commons. In E. Boyd \& C. Folke (Eds.), Adapting institutions: Governance, complexity and socialecological resilience (pp. 101-124). Cambridge University Press.

Colding, J., \& Barthel, S. (2013). The potential of "urban green commons" in the resilience building of cities. Ecological Economics, 86, 156-166.

Colding, J., Barthel, S., \& Samuelsson, K. (2020). Supporting bottom-up human agency for adapting to climate change. One Earth, 3(4), 392-395. https://doi.org/ 10.1016/j.oneear.2020.09.005

Colding, J., Barthel, S., Bendt, P., Snep, R., van der Knaap, W., \& Ernstson, H. (2013). Urban green commons: Insights on urban common property systems. Global
Environmental Change, 23, 1039-1051.

Colding, J., \& Folke, C. (2001). Social taboos: Invisible systems of local resource management and biodiversity conservation. Ecological Applications, 11(2), 584-600.

Conrad, D., \& Sinner, A. (2015). Creating together: Participatory, community-based, and collaborative arts practices and scholarship across Canada. Wilfrid Laurier University Press.

de Vaujany, F.-X., Leclercq-Vandelannoitte, A., Munro, I., Nama, Y., \& Holt, R. (2021). Control and surveillance in work practice: Cultivating paradox in "new" modes of organizing. Organization Studies, 42(5), 675-695.

Dominelli, L. (2020). The Routledge handbook of green social work. Routledge.

Dryzek, J. S., \& Niemeyer, S. (2019). Deliberative democracy and climate governance. Nature Human Behaviour, 3, 411-413.

DTZ. (2014). The coworking revolution. https://docplayer. net/11750254-The-coworking-revolution.html

Eriksson, F. (2021). Kan koldioxidutsläppen reduceras med hjälp av coworking spaces? En mixad metodstudie om arbetspendling relaterat till coworking [Can carbon dioxide emissions be reduced with the help of coworking spaces? A mixed method study about coworking] [Doctoral thesis, University of Gävle]. Digitala Vetenskapliga Arkivet. https://www.diva-portal.org/smash/get/diva2: 1573263/FULLTEXT01.pdf

Estes, R. J. (1997). Social work, social development and community welfare centers in international perspective. International Social Work, 40(1), 43-55.

Feinberg, A., Ghorbani, A., \& Herder, P. M. (2020). Commoning toward urban resilience: The role of trust, social cohesion, and involvement in a simulated urban commons setting. Journal of Urban Affairs. Advance online publication. https://doi.org/ 10.1080/07352166.2020.1851139

Folke, C., Pritchard, L., Berkes, F., Colding, J., \& Svedin, U. (2007). The problem of fit between ecosystems and institutions: ten years later. Ecology and Society, 12(1). http://www.ecologyandsociety.org/ vol12/iss1/art30

Fook, J. (2016). Social work: A critical approach to practice. SAGE.

Gadgil, M., \& Vartak, V. D. (1974). The sacred groves of Western Ghats in India. Economic Botany, 30, 152-160.

Gertler, M. (2003). Tacit knowledge and the economic geography of context, or the undefinable tacitness of being (there). Journal of Economic Geography, 3, 75-99.

Goswami, M. (2020). Revolutionizing employee employer relationship via gig economy. Materials Today: Proceedings. Advance online publication. https://doi.org/10.1016/j.matpr.2020.09.436

Hardin, G. (1968). The tragedy of the commons. Science, $162,1243-1248$. 
Harris, S., Mata, E., Plepys, A., \& Katzeff, C. (2021). Sharing is daring, but is it sustainable? An assessment of sharing cars, electric tools and offices in Sweden. Resources, Conservation \& Recycling, 170. https:// doi.org/10.1016/j.resconrec.2021.105583

Hess, C. (2008). Mapping the new commons. SSRN Electronic Journal. https://doi.org/10.2139/ssrn. 1356835

Holmgren, M., Kabanshi, A., Langeborg, L., Barthel, S., Colding, J., Eriksson, O., \& Sörqvist, P. (2019). Deceptive sustainability: Cognitive bias in people's judgment of the benefits of $\mathrm{CO} 2$ emission cuts. Journal of Environmental Psychology, 64, 48-55. https://doi. org/10.1016/j.jenvp.2019.05.005

Hook, A., Court, V., Sovacool, B. K., \& Sorrell, S. (2020). A systematic review of the energy and climate impacts of teleworking. Environmental Research Letters, 15. https://doi.org/10.1088/1748-9326/ab8a84

Horelli, L., Saad-Sulonen, J., Wallin, S., \& Botero, A. (2015). When self-organization intersects with urban planning. Planning Practice \& Research, 30(3). https://doi.org/10.1080/02697459.2015.1052941

IPCC. (2021). The sixth assessment report. https://www. ipcc.ch/report/ar6/wg1

Jansson, Å., \& Nohrstedt, P. (2001). Carbon sinks and human freshwater dependence in Stockholm county. Ecological Economics, 39, 361-370.

Kabat, P., van Vierssen, W., Veraart, J., Vellinga, P., \& Aerts, J. (2005). Climate proofing the Netherlands. Nature, 438, 283-284. https://doi.org/ $10.1038 / 438283 a$

Kohn, M. (2001). The power of place: The house of the people as counter public. Polity, 33(4), 503-526.

Kohn, M. (2004). Brave new neighborhoods. The privatization of public space. Routledge.

Krasny, M., \& Tidball, K. (2009). Community gardens as contexts for science, stewardship, and civic action learning. Cities and the Environment, 2, 1-18.

Kylili, A., Afxentiou, N., Georgiou, L., Panteli, C., MorsinkGeorgalli, P. Z., Panayidou, A., \& Fokaides, P. A. (2020). The role of remote working in smart cities: Lessons learnt from COVID-19 pandemic. Energy Sources, Part A: Recovery, Utilization, and Environmental Effects. Advance online publication. https:// doi.org/10.1080/15567036.2020.1831108

Linn, K. (1999). Reclaiming the sacred commons. New Village, 1, 42-49.

Luo, Y., \& Chan, R. C. (2020). Production of coworking spaces: Evidence from Shenzhen, China. Geoforum, 110, 97-105. https://doi.org/10.1016/ j.geoforum.2020.01.008

McGinnis, M., \& Ostrom, E. (1992). Design principles for local and global commons [Paper presentation]. Linking Local and Global Commons, Cambridge, MA, USA.

Moriset, B. (2013). Building new places of the creative economy. The rise of coworking spaces. HAL-SHS Archives. https://halshs.archives-ouvertes.fr/halshs00914075/document
Nyborg, K., Anderies, J. M., Dannenberg, A., Lindahl, T., Schill, C., Schlüter, M., Neil Adger, W., Arrow, K. J., Barrett, S., Carpenter, S., Stuart Chapin, F., III, Crépin, A.-S., Daily, G., Ehrlich, P., Folke, C., Jager, W., Kautsky, N., Levin, S. A., Madsen, O. J., . . . de Zeeuw, A. (2016). Social norms as solutions. Science, 354(6308), 42-43.

Oddsberg, J. (2011). An analysis of the potential of local stewardship as a management mode for increasing and enhancing ecosystem services in the urban landscape [Master's thesis, Stockholm University]. Digitala Vetenskapliga Arkivet. http://www.diva-portal. org/smash/record.jsf?pid=diva2\%3A448489\&dswid= $-7693$

Ohnmacht, T., Z'Rotz, J., \& Dang, L. (2020). Relationships between coworking spaces and $\mathrm{CO} 2$ emissions in work-related commuting: First empirical insights for the case of Switzerland with regard to urban-rural differences. Environmental Resource Communication, 2. https://doi.org/10.1088/2515-7620/abd33e

Okvat, H., \& Zautra, A. (2011). Community gardening: A parsimonious path to individual, community, and environmental resilience. American Journal of Community Psychology, 47, 374-387.

Oldenburg, R. (1989). The great good place: Cafes, coffee shops, community centers, beauty parlors, general stores, bars, hangouts, and how they get you through the day. Paragon House.

Ostrom, E. (1990). Governing the commons. The evolution of institutions for collective action. Cambridge University Press.

Ostrom, E. (2005). Understanding institutional diversity. Princeton University Press.

Ostrom, E. (2008). The challenge of common pool resources. Environment, 50, 8-21.

Ostrom, E., \& Schlager, E. (1996). The formation of property rights. In S. Hanna, C. Folke, \& K.-G. Mäler (Eds.), Rights to nature (pp. 127-156). Island Press.

Pearsall, H., Gachuz, S., Rodriguez Sosa, M., Schmook, B., van der Wal, H., \& Gracia, M. A. (2017). Urban community garden agrodiversity and cultural identity in Philadelphia, Pennsylvania, U.S. Geographical Review, 107, 476-495.

Polanyi, M. (1966). The tacit dimension. Routledge.

Popple, K. (2015). Analysing community work: Theory and practice. Open University Press.

Pyles, L. (2020). Progressive community organizing: Transformative practice in a globalizing world. Routledge.

Räisänen, J., Ojala, A., \& Tuovinen, T. (2020). Building trust in the sharing economy: Current approaches and future considerations. Journal of Cleaner Production, 279(37). https://doi.org/10.1016/j.jclepro. 2020.123724

Raworth, K. (2012). A safe and just space for humanity: Can we live within the doughnut? (Oxfam Discussion Paper). Oxfam International. https://www-cdn. oxfam.org/s3fs-public/file_attachments/dp-a-safe- 
and-just-space-for-humanity-130212-en_5.pdf

Rivas, J. G., Rodríguez-Serrano, A., Loeb, S., Teoh, J. Y. C., Ribal, M. J., Bloemberg, J., Cattog, J., Dow, J. N., van Poppeli, H., González, J., Estebank, M., \& Rodriguez Socarrás, M. (2020). Telemedicine and smart working: Spanish adaptation of the European Association of Urology recommendations. Actas Urológicas Españolas (English Edition), 44(10), 644-652. https:// doi.org/10.1016/j.acuroe.2020.08.007

Rockström, J., Steffen, W., Noone, K., Persson, Å., Stuart Chapin, F., III, Lambin, E., Lenton, T. M., Scheffer, M., Folke, C., Schellnhuber, H., Nykvist, B., De Wit, C. A., Hughes, T., van der Leeuw, S., Rodhe, H., Sörlin, S., Snyder, P. K., Costanza, R., Svedin, U., . . F Foley, J. (2009). A safe operating space for humanity. Nature, 461, 472-475. https://doi.51org/10.1038/461472a

Rogge, N., Theesfeld, I., \& Strassner, C. (2018). Social sustainability through social interaction: A national survey on community gardens in Germany. Sustainability, 10(4), 1-18. https://doi.org/10.3390/ su10041085

Roof, K., \& Oleru, N. (2008). Public health: Seattle and King County's push for the built environment. Journal of Environmental Health, 71(1), 24-27.

Ruitenbeek, J., \& Cartier, C. (2001). The invisible wand: Adaptive co-management as an emergent strategy in complex bio-economic systems. Center for International Forestry Research.

Rydin, Y., \& Pennington, M. (2000). Public participation and local environmental planning: The collective action problem and the potential of social capital. Local Environment, 5, 153-169.

Saldivar-Tanaka, L., \& Krasny, M. E. (2004). Culturing community development, neighborhood open space, and civil agricultural: The case of Latino community gardens in New York City. Agriculture and Human Values, 21, 399-412.

Schroeder, A. N., Bricka, T. M., \& Whitaker, J. H. (2019). Work design in a digitized gig economy. Human Resource Management Review, 31(1). https://doi. org/10.1016/j.hrmr.2019.100692

Scott, A. J. (2006). Creative cities: Conceptual issues and policy questions. Journal of Urban Affairs, 28, 1-17.

Sjöberg, S., \& Kings, L. (2021). Suburban commons: The rise of suburban social movements and new urban commons in marginalized neighborhoods in Stock- holm. Nordic Social Work Research. Advance online publication. https://doi.org/10.1080/2156857X. 2021.1982753

Sjöberg, S., Rambaree, K., \& Jojo, B. (2015). Collective empowerment: A comparative study of community work in Mumbai and Stockholm. International Journal of Social Welfare, 24(4), 364-375.

Speak, A., Mizgajski, A., \& Borysiak, J. (2015). Allotment gardens and parks: Provision of ecosystem services with an emphasis on biodiversity. Urban Forestry \& Urban Greening, 14, 772-781.

Stavrides, S. (2016). Common space: The city as commons. Zed Books.

Swedish Environmental Research Institute. (2019). Delningens potential [The potential of sharing]. https://www.ivl.se/download/18.20b707b7169f355 daa76ed5/1572337516186/C371.pdf

Tomlinson, J. (2003). Globalization and cultural identity. In D. Held \& A. McGrew (Eds.), The global transformations reader (2nd ed., pp. 269-277). Polity Press.

Vincent-Jones, P. (2000). Contractual governance: Institutions and organizational analysis. Oxford Journal of Legal Studies, 20, 317-351.

Waters-Lynch, J., Potts, J., Butcher, T., Dodson, J., \& Hurley, J. (2016). Coworking: A transdisciplinary overview. SSRN. https://dx.doi.org/10.2139/ ssrn. 271221

Webb, J., Stone, L., Murphy, L., \& Hunter, J. (2021). The climate commons. How communities can thrive in a climate changing world. Institute for Public Policy Research. https://www.ippr.org/research/ publications/the-climate-commons

Wenger, E. (1998). Communities of practice. Learning, meaning and identity. Cambridge University Press.

Xie, B., Hurlstone, M. J., \& Walker, I. (2018). Correct me if I'm wrong: Groups outperform individuals in the climate stabilization task. Frontiers in Psychology, 9. https://doi.org/10.3389/fpsyg.2018.02274

Yan, M. C. (2004). Bridging the fragmented community: Revitalizing settlement houses in the global era. Journal of Community Practice, 12(1/2), 51-69.

Yang, E., Bisson, C., \& Sanborn, B. E. (2019). Coworking space as a third-fourth place: Changing models of a hybrid space in corporate real estate. Journal of Corporate Real Estate, 21(4), 324-345. https://doi.org/ 10.1108/JCRE-12-2018-0051

\section{About the Authors}

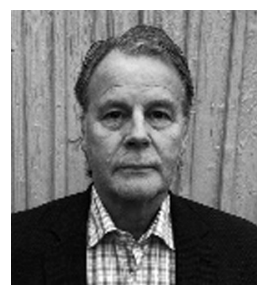

Johan Colding is a professor in sustainability science at the University of Gävle and at the Beijer Institute of Ecological Economics. He holds a PhD and an associate prof. degree in natural resource management from Stockholm University. Johan is a highly cited scientist with expertise in urban ecology, ecosystem management, institutions, resilience science, and social-ecological systems analysis. 


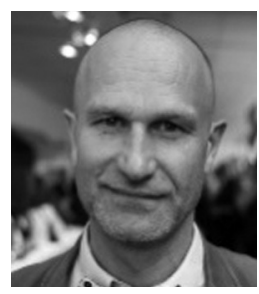

Stephan Barthel is a professor in sustainability science at the University of Gävle, Sweden, and an associated researcher at the Stockholm Resilience Centre, Stockholm University. He leads projects and programs on urban sustainability, methods development in design and planning, and knowledge co-creation for a fair climate transformation. He holds a PhD in natural resource management and an associate prof. degree in geo-spatial information science.

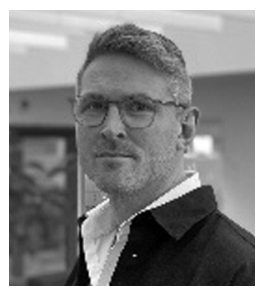

Robert Ljung is an associate professor in environmental psychology. He is working with process-leading analysis at the Swedish Agency for Work Environment Expertise and the University of Gävle, Sweden. His research interest is social sustainability and behavior change. His research field covers the relation between work environment, cognitive performance, and behavior. Robert is also a member of the advisory board of experts for the organization Nudgd.

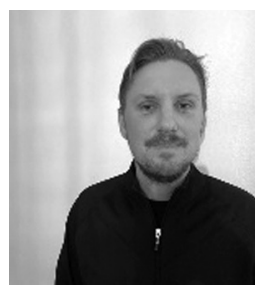

Felix Eriksson holds a bachelor's degree in environmental engineering from the University of Gävle, Sweden. His research interest covers the environmental outcomes of coworking spaces through a mixture of quantitative and qualitative methods. Felix is currently prospecting grounds for future opportunities within this area of work.

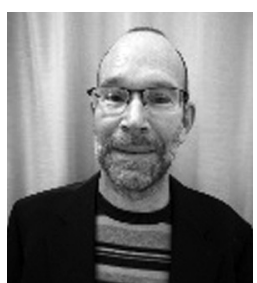

Stefan Sjöberg is an associate professor in social work at the University of Gävle, Sweden, and holds a PhD in sociology from Uppsala University, Sweden. He leads a research program on urban commons within the frame of the strategic research area on sustainable cities at the University of Gävle. Stefan leads research projects focusing on the transformation of the Swedish welfare model, community work, and social mobilization in marginalized neighborhoods. 